\title{
Eightfold ways
}

Peter J. Smith

Catastrophism: Systems of Earth History. By Richard Huggett. Arnold: 1990. Pp. 246. £35. Distributed by Routledge in the United States, $\$ 44.95$.

THE conflict during the early nineteenth century between the proponents of catastrophism and uniformitarianism is one of the more enduring part-myths in the history of geology. In its more extreme, picture-book form it pits irredeemable baddies (the catastrophists) against impeccable goodies (the uniformitarianists), with ultimate victory going to the white knight Sir Charles Lyell acting, in part, under the historical influence of James Hutton. That there were differing views on the nature and causes of geological processes and events is undoubtedly true; but as the revisionists, led by Tony Hallam and Stephen Jay Gould, have so ably shown over the past decade, shades of opinion were more complex than the Henty school of historians would have had us believe. Huggett's main achievement is not only to reinforce the revisionist line in respect of the early geologists but to demonstrate that the uniformitarianist rhetoric of the 'victors' has been at odds with the reality of much geological thought since at least the late nineteenth century.

Part of the barrier to understanding here has been the inability or unwillingness of working geologists to become conversant with the precise ground rules for debate, which is no doubt why Huggett takes the early part of his book to define terminology and spell out the fundamental philosophical concepts involved. Essential though this may seem, it is a

\section{New Journals}

This year Nature's annual new journals review supplement will appear in the issue of 11 October. Publishers and learned societies are invited to submit journals for review, taking note of the following criteria:

- Journals which first appeared after June 1988 , and which issued at least four separate numbers by the end of April 1990, will be considered for review. The deadline for submission is the end of June.

- Journals covering any aspect of science are eligible, although those dealing with clinical medicine, engineering and pure mathematics are excluded, as are publications of abstracts. - Frequency of publication must be at least three times a year.

- The main language used must be English. Translation journals in English are eligible.

When submitting journals for review, please send at least four different issues (the first, the most recent and any two others) of each title as soon as possible to: Book Review Editor, Nature, 4 Little Essex Street, London WC2R 3LF, UK or 1137 National Press Building, Washington DC 20045, USA. courageous move all the same, for, being akin to insisting that the learning of tables is a necessary prerequisite for arithmetic operations, it involves the severe risk of turning geologists off. They would be wise to master this section, however, not only because Huggett goes on to clarify the nature of the work of individual geologists in terms of classification systems set up therein, but because the failure hitherto to assimilate the fine philosophical distinctions explains just why it is that (to adapt an adage more usually applied to economists) whenever six of today's Earth scientists are gathered together there will emerge seven different definitions of uniformitarianism.

The fact is that Lyell proposed not one but four distinct uniformities - of law, of process (actualism), of rate (gradualism) and of state (steady-statism) - the first two of which are methodological principles to which most geologists have hitherto subscribed and the last two of which are substantive claims about the Universe that Lyell partially disguised as methodological principles. All have their attendant confusions. The uniformity of law could be regarded as tautological, although that is the least of a geologist's worries. More seriously, the uniformity of rate raises the vexed issue of the definition of rate in the context of periodic, cyclical and episodic change and, not least, of the potential of uniform-rate systems to generate catastrophic modes of action. The conclusions reached here then have implications for the precise meaning of the uniformities of process and state.

The picture is further confused by the fact that catastrophists also subscribed to the principle of the uniformity of law and, in part, to that of the uniformity of process. On the other hand, in their early manifestation they were also deists, semideists or theists, but then lyellian uniformitarianists were deists too. And irrespective of by what or whom catastrophes are caused, and whether they are externally imposed (by either natural or divine process) or the consequence of internal crises, just how are 'catastrophes' to be defined anyway, given their wide range of spatial and secular scales?

Huggett has done a truly magnificent job in separating out the many conceptual strands that weave their way through the history of geology, ending up with two eightfold classification schemes (one each for the inorganic and organic worlds) into which he proceeds to fit theories of life and Earth old and new. The result is a brief history of geological thought that demonstrates convincingly that, notwithstanding uniformitarianist claims to the contrary, catastrophism of various forms and scales has almost always been an essential component of geological theory. This also includes geographical theory, incidentally, for Huggett has chosen to use more examples from his own sphere of the Earth sciences than the average geological reader will be used to.

This wider frame of reference is all to the good, although I rather suspect that Huggett's geographical background may have led him to underestimate somewhat the degree to which modern geologists have been willing to accommodate natural catastrophism. There is, in fact, a curious paradox here that requires further examination. It is undeniably true, as Huggett says, that geologists are so wedded to the idea of what they understand to be uniformitarianism that in order to reconcile this devotion with modern geological theory they have had to resort ever more desperately to such ludicrous terms as "episodic uniformitarianism' and even 'catastrophic uniformitarianism'. On the other hand, one can only look with astonishment at the sheer number of Earth scientists who have been able to accept, apparently without turning a hair, the extraterrestrialcatastrophist explanation of the iridium layer (and hence, by extension, the mass extinctions) at the Cretaceous-Tertiary boundary. I don't recall reading over the past decade a single objection to the asteroid impact hypothesis on the purely philosophical grounds that such an impact could be interpreted as non-uniformitarianist. Objections there have been plenty, but most conspicuously from geologists peddling an alternative explanation that itself involves catastrophism of a sort. Why are professed and actual beliefs so ill-matched?

Peter J. Smith is in the Department of Earth Sciences, The Open University, Milton Keynes MK7 6AA, UK, and Editor of Geology Today.

\section{New in paperback}

- The Fate of the Forest, by S. Hecht and A. Cockburn, tells the story of the delusions and greed that have shaped the Amazon's history. Subtitled Developers, Destroyers and Defenders of the Amazon, it was reviewed in Nature by M. Fox $(342,313 ; 1989)$. Penguin, price $£ 5.99$. - Johns Hopkins University Press has just issued in paperback Back to Nature: The Arcadian Myth in Urban America, by P. J. Schmitt, originally published by Oxford University Press in 1969. Schmitt describes how the American urban middle class became involved with the countryside from the turn of the century to just after World War 1 - its search for virtue in nature. Price is $\$ 12.95$.

- New in paperback from Princeton University Press is Contoversy in Victorian Geology by J. A. Secord. The book provides a new interpretation of the Cambrian-Silurian debate, relating the dispute to the social background of British geology at the time. Price, \$16.95.

- A delightful facsimile edition of $N$. Tinbergen's classic Social Behaviour in Animals has been issued by Chapman and Hall. The book is based on Tinbergen's own research from which emerged the discipline of ethology the scientific study of animal behaviour. Originally published in 1953, the book contains the author's original sketches and photographs. Price is $£ 12.95$. 